\title{
Connected VCs and strategic alliances: Evidence from biotech companies ${ }^{\text {Hh }}$
}

\author{
Leonhard Brinster ${ }^{a}$, Tereza Tykvová ${ }^{b, *}$ \\ a University of Hohenheim, Chair of Corporate Finance, Wollgrasweg 49, 70599 Stuttgart, Germany \\ ${ }^{\mathrm{b}}$ University of St. Gallen, Chair of Private Markets and Alternative Investments, Unterer Graben 21, 9000 St. Gallen, Switzerland
}

\section{A R T I C L E I N F O}

\section{JEL classification:}

G24

L24

L26

Keywords:

Venture capital

Strategic alliance

Prior ties

Connected venture capital investors

Transaction and information costs

Biotechnology

\begin{abstract}
A B S T R A C T
We study a new channel through which portfolio companies benefit from ties among venture capitalists (VCs). By tracing individual VCs' investment and syndication histories, we show that VCs' ties improve companies' access to strategic alliance partners. While existing studies demonstrate that alliances are more frequent among companies sharing the same VC, we provide evidence that alliances are also more frequent among companies indirectly connected through VC syndication networks. In addition, our results suggest that VCs' ties mitigate asymmetric information problems that arise when alliances are formed. Finally, strategic alliances between companies from connected VCs' portfolios tend to perform well. We demonstrate that this type of alliance is associated with higher IPO chances. We also address alternative explanations and related endogeneity concerns.
\end{abstract}

\section{Introduction}

Venture capitalists (VCs) are financial intermediaries that offer funds to high-growth companies. Besides funds, they add value to these companies by providing coaching and mentoring. In addition, they facilitate high-growth companies' access to "third parties" such as further investors, human capital, suppliers, customers, public institutions, industry associations, and strategic alliance partners (e.g., Sahlman, 1990). In this study, we focus on VCs' role in the formation of strategic alliances. Strategic alliances are an important source of value for young innovative companies because they link them to other companies with complementary resources (Mitchell and Singh, 1996; Pisano, 1994; Shan et al., 1994; Singh and Mitchell, 2005; Stuart, 2000). These links may improve companies' prospects, and help them grow and reach their goals (e.g., Ozmel et al., 2013a). They may also be associated with higher IPO chances (e.g., Brinster et al., 2020).

Prior research suggests that VCs increase the alliance activity in their portfolio companies (e.g., Ozmel et al., 2013b). From the existing literature, we also know that two VC-backed companies that obtained funding from the same VC form alliances more often than those that were financed by two different VCs do (Lindsey, 2008). This paper investigates whether portfolio companies benefit from bilateral ties among VCs when they form strategic alliances. We ask the question whether two companies more often form an

We are grateful for the access to Thomson One VentureXpert, Dow Jones VentureSource, S\&P Capital IQ, and Patstat provided by the Hohenheim Datalab (DALAHO), University of Hohenheim. We thank two anonymous reviewers, Douglas Cumming (the editor), Ralf Elsas, Daniel Forbes, Marc Frattaroli, Fatemeh Hosseini, Sophie Manigart, and Vikram Nanda for valuable comments.

* Corresponding author.

E-mail addresses: leonhard.brinster@uni-hohenheim.de (L. Brinster), tereza.tykvova@unisg.ch (T. Tykvová). 
alliance if they were backed by VCs that are connected with each other. We expect to find a positive answer for at least three reasons. First, two VCs that are connected may mitigate the transaction costs of alliance formation by helping their portfolio companies to establish contacts with portfolio companies from the connected VC portfolio. Second, a connected VC can reduce adverse selection costs. Since a connected VC enjoys a higher level of trust than an unknown VC does, it may certify its portfolio company quality for the partner company. Third, for reputational reasons, connected VCs may protect the counterparty from moral hazard and expropriation risks by limiting misconduct in their portfolio companies.

To illustrate what we mean by connected VCs, Fig. 1 shows, on the right-hand side, an example of a connected-VC-backed alliance between company $\mathrm{X}$ (backed by $\mathrm{VC}_{1}$ ) and company $\mathrm{Y}$ (backed by $\mathrm{VC}_{2}$ ). $\mathrm{VC}_{1}$ and $\mathrm{VC}_{2}$ are "connected" because they invested jointly in company $\mathrm{Z}$ in the past. For comparison purposes, we show a same-VC-backed alliance on the left-band side. Companies A and $\mathrm{B}$, which were both backed by $\mathrm{VC}_{1}$, pair in an alliance.

For example, Exosome Diagnostics (backed by Forbion Capital Parters) and Qiagen N.V. (backed by TVM Life Science Venture Capital) announced a strategic alliance in July 2013. Prior to this date, Forbion and TVM have jointly invested in Argos Therapeutics (through several rounds between April 2001 and August 2012), in Cell Based Delivery (in April 2002), in Acorda Theraupeutics (in May 2003) and in bluebird bio (in March 2010, April 2011 and July 2012).

We also investigate whether bilateral connections between VCs are more important when transaction and information costs increase; that is, when the geographical and technological distances between the potential alliance partners grow. Finally, we are interested whether alliances between companies from connected VCs' portfolios are associated with better exits.

To answer these questions, we rely on a dataset of 1073 strategic alliances formed between 2004 and 2019 by US biotech companies. In 427 cases (39.79\%), both the biotech company and the alliance partner are VC-backed. In 52 of these cases, both alliance partners share the same VC. Alliances between companies from connected VCs' portfolios are even more common: we observe 197 such alliances in our sample.

Our results suggest that bilateral ties between VCs tend to improve companies' access to strategic alliance partners from connected VCs' portfolios. We address alternative non-causal explanations for the positive link between bilateral VC connections and alliance activity between companies from connected VCs' portfolios. We are aware that VCs with large networks invested with many different VCs in the past. Thus, the probability that a connected VC will participate in the alliance with a particular partner is, in general, higher for VCs with large networks than for VCs with small networks (Ozmel et al., 2013b). To illustrate, imagine a very large VC that already invested with all other VCs in the past. Consequently, this VC will have ties to all VCs in all VC-backed partners. Consequently, the effect we observe could be the overall-network-effect instead of the bilateral-ties-effect. Therefore, in our analyses, we disentangle these two effects and measure the bilateral-ties-effect on the top of the overall-network-effect.

Another alternative explanation for the positive relationship between bilateral ties and alliances could arise from VC specialization. Two VCs with the same industry focus are more likely to be connected through prior joint investments. At the same time, companies from the same industry could more likely form an alliance than companies from different industries would. Consequently, we might observe strategic alliances between companies financed by connected VCs more often because these VCs have a similar investment focus. We indeed find that strategic alliances between the portfolio companies of VCs with a similar investment focus are more likely to occur. However, the effect of bilateral ties remains highly statistically significant and positive when we control for the similarity of the investment focus of the two VCs.

We also account for a non-random matching between alliance partners. We want to link the probability that biotech company $\mathrm{X}$ and strategic partner Y form an alliance to proxies that capture how closely the VCs of X and Y are connected (if they are connected). To analyze this probability, we build a sample of counterfactual alliances; that is, alliances that were possible but that did not occur. We run a random matching. By constructing the counterfactual sample, we focus on potential partners that are not in a strategic alliance with another biotech firm yet. In addition, we address the potential endogeneity of syndicate formation to exclude that our results

Same-VC-backed alliance

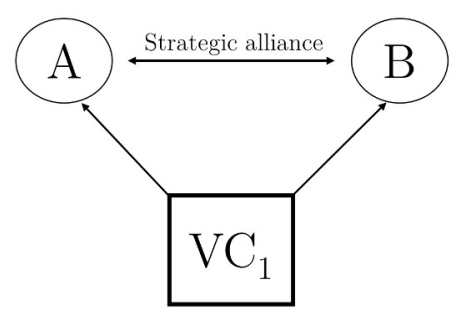

\section{Connected-VC-backed alliance}

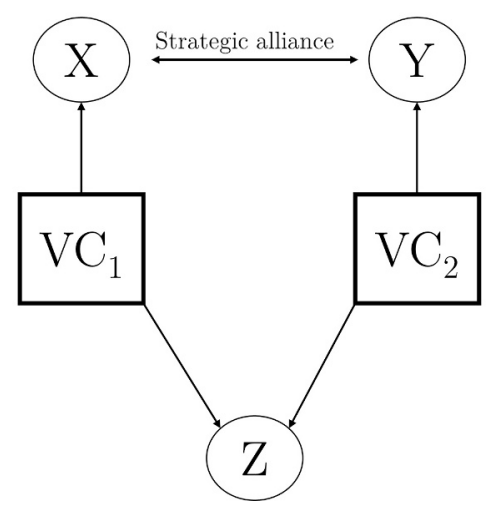

Fig. 1. Same-VC-backed and connected-VC-backed strategic alliances. 
reflect spurious correlations, which could happen if specific VC-dyad characteristics drove both the syndicate formation and the strategic alliance formation.

We focus on the biotech industry. Given the large funding needs and long product development cycles, young biotech companies often enter strategic alliances with more established partners to complement their resources. One typical example from our sample is a strategic alliance between a young VC-backed biotech company Adimab LLC (founded in 2007) and Cascadian Therapeutics Inc., an established biotech company (founded in 1985). According to the annual report of Cascadian Therapeutics from 2017 (https:// www.sec.gov/Archives/edgar/data/1412067/000119312518075320/d640776d10k.htm), the two companies signed an agreement about a strategic alliance "for the discovery of novel antibodies against immunotherapy targets in oncology" in 2014 . The collaboration started at the early preclinical development stage. The role of Cascadian Therapeutics, as the established partner, was to provide research funding for the development of these antibodies. Adimad was entitled to "success-based development milestone payments of up to USD 17 million and a low single-digit royalty based on net sales." In addition, Cascadian Therapeutics had the "sole responsibility for the manufacture, development and commercialization of any antibody product candidates that result from the collaboration."

This research contributes to four main strands of the literature. First, we provide new findings on the relationship between VC financing and strategic alliance activity. This topic attracted attention since the seminal study by Lindsey (2008), who finds that strategic alliances are more common among companies financed by the same VC. While she considers positive effects of VC financing on alliance formation only within a particular VC's existing and prior portfolios, we expect to find a positive effect also between the portfolios of connected VCs. Another related study is that by Wang et al. (2012), who show that larger VC syndicates are associated with a higher number of strategic alliances on average. While they only look at the relationship between the overall VC network and the alliance activity, we delve into the effects of individual prior ties within VC syndicates on the choice of a particular strategic partner. More specifically, we extend the existing knowledge by analyzing how prior ties between two VCs affect the cooperation patterns of companies backed by these VCs. We expect that VC-backed companies are more likely to engage in strategic alliances with companies in which a connected VC invested. Hereby, connected VCs may reduce transaction costs for the partners' portfolio companies. In addition, connected VCs may mitigate the adverse selection and moral hazard costs that arise between alliance partners.

We are the first to analyze whether portfolio companies benefit from their VCs' prior bilateral ties through a better access to strategic alliance partners from individual network VCs' portfolios. Ozmel et al. (2013b) mention that prominent VC networks may help portfolio companies find appropriate alliance partners. They show that larger VC network size is positively associated with alliance formation. However, they do not collect data on individual VCs' financing histories. Our study builds on Ozmel et al. (2013b)'s findings. However, instead of relying on the overall VC network size only, we offer a direct evidence by tracing specific VC ties. We look at the individual VC financing histories of both alliance partners and trace the prior joint bilateral ties between VCs participating on both sides of the alliance. We then analyze whether these ties (and their intensity) matter for alliance pairing. We demonstrate that, while controlling for the overall network size, bilateral VC ties help companies build alliances with partners from connected VCs' portfolios. In addition, these ties matter more when transaction and information costs increase.

Second, we add to the literature that focuses on the effects of VC syndication and networks. Recent theoretical and empirical work studies the involvement of several VCs as a common means to access new financial and managerial resources. The findings suggest that VCs and portfolio companies benefit from cooperation among VCs. In essence, cooperation among VCs affects the main drivers of performance: sourcing high-quality deals, and promoting growth and innovations in the portfolio companies. The benefit of involving co-investors comes from the heterogeneous skills and information sets that different VCs contribute to the selection and management of the portfolio companies. Lerner (1994) suggests that the evaluation of the same venture proposal by different VCs operating in a syndicate reduces adverse selection. From existing research we know that VCs share access to deals with connected VCs (Tian, 2012). We find that VCs may share access to potential cooperation partners from their portfolios in a similar way. Brander et al. (2002) see the VC industry as a pool of productive resources in which a VC can access resources from another VC through joint investments. Other studies demonstrate that cooperation among VCs yields higher sales or employment growth (e.g., Grilli and Murtinu, 2014; Tian, 2012) and more innovations (e.g., Bertoni and Tykvová, 2015). Hochberg et al. (2007) analyze the performance consequences of the ties formed in the US venture capital industry and show that portfolio companies whose investors are better connected perform substantially better. We contribute to this research by showing how prior ties among VCs are related to the formation of ties between portfolio companies.

Third, we contribute to the more general literature on VC value added. Numerous studies argue that VCs add value to their portfolio companies beyond money. VCs monitor their portfolio companies, which reduces agency costs (Gompers, 1995; Lerner, 1995). In addition, their companies benefit from VCs' support in important strategic decisions and activities (see, e.g., Cumming et al., 2005; Hellmann and Puri, 2002; Hochberg et al., 2007; Hochberg, 2012; Kaplan and Strömberg, 2004). While many studies demonstrate value creation in VC-backed companies, ${ }^{1}$ though only a few studies focus on a specific area of involvement through which VCs add value. Our study contributes to filling this gap by shedding light on one of these areas, namely, strategic alliance formation. Moreover, we find that strategic alliances between portfolio companies from connected-VCs' portfolios are associated with better exits.

Finally, we add to the literature in the management and strategy area that argues that indirect ties result in direct ties Gulati (1995), and that networks are related to alliance formation (Gulati, 1998; Gulati, 1999). Gulati (1995) analyzes the social network in which a

\footnotetext{
${ }^{1}$ For example, there is empirical evidence for a positive relation between venture capital financing and innovation at the country-level (e.g., Kortum and Lerner, 2000; Popov and Roosenboom, 2012) and portfolio company-level (e.g., Hellmann and Puri, 2000; Bertoni and Tykvová, 2015). Other studies show positive effects on employment or sales growth, valuations, and survival (for a survey, see Tykvová, 2018).
} 
company is embedded, because such networks potentially provide valuable information about partners. Therefore, the position of a company in a social network has an impact on future alliance formation; that is, the smaller the distance between two companies is, the more likely it is that they will form an alliance. Furthermore, networks may serve as a governance mechanism for inter-company connections (e.g., Robinson and Stuart, 2007b). The authors argue that "information conveyed through network ties is not necessarily available to all network members" and that in strategic alliances, companies "rely less on explicit control mechanisms such as equity ownership and more on implicit, network-based control." We show that prior connections between VCs increase the probability of alliance formation, arguably because prior connections result in a more efficient screening result, and thus in less need for explicit control mechanisms such as equity ownership. Singh (2008) reports that social networks are important predictors of intraregional and intracompany knowledge flows. Our results demonstrate that prior connections between the VC-investors can mitigate the negative effects of greater distance on alliance formation. To summarize, we complement this literature by focusing on prior ties between VCs and their effects on networking among portfolio companies in the form of alliance formation.

The remainder of the paper is structured as follows. The next section presents the theoretical background for this study. We discuss our dataset in Section 3, where we also provide the descriptive statistics of the VC-backed biotech companies and their strategic alliances. Section 4 first describes the methodology we use to construct the sample of counterfactual alliances. Next, we compare the characteristics of the realized and counterfactual alliances and discuss potential endogeneity in syndicate formation. Section 5 shows our empirical results and Section 6 concludes.

\section{Theoretical background}

Despite their popularity and the acclaimed benefits (e.g., Chan et al., 1997), many strategic alliances fail to meet expectations. For example, Das and Teng (2000) report that 30 to 50\% of strategic alliances do not succeed. Reuer et al. (2002) report that 34\% of research alliances are failures and Sadowski and Duysters (2008) claim that more than 50\% of technology alliances do not survive.

At first, it is costly to find an appropriate partner and the selection process suffers from information asymmetries since the potential partner's quality is unknown to the other party (Owen and Yawson, 2013). Strategic alliances appear fragile for several reasons. After the two parties form an alliance, each may be exposed to moral hazard. The joint involvement in a business generates incentives to free ride on the information acquisition and the effort of the other party (Das and Teng, 1999, 2001; Fonti et al., 2017). Additionally, close collaboration in the form of a strategic alliance may lead to information leakage to the other party, which is a strategic partner on the one hand, but also a competitor that may misuse this information (Hamel et al., 1989) on the other hand. Consequently, each company may consider expropriation risks when deciding if to collaborate and with which partner (Gulati and Singh, 1998).

Firms can reduce asymmetric information, moral hazard, and expropriation risks by screening and monitoring the counterparty (Kaplan and Strömberg, 2001, 2004; Lerner, 1995). However, the ex-ante quality and ex-post actions of the counterparty are costly to observe, so screening and monitoring will prohibitively increase the costs of alliance formation and cooperation (Dyer and Chu, 2003; Gulati and Singh, 1998; White and Siu-Yun Lui, 2005). Under these circumstances, it seems challenging for young biotech companies to find well-fitting and reliable strategic partners that are willing to invest.

When parties find it costly to accurately evaluate the quality of resources that partners can bring to the table, informed active investors and their certification of partners can be valuable (Hochberg et al., 2007; Megginson and Weiss, 1991). In this environment, connected VCs may provide several benefits. VCs, as active investors, have access to detailed information about the companies they finance, and hence understand their portfolio companies' needs (Barry et al., 1990). This understanding may help young firms find appropriate partners (Aoki, 2000). Consequently, they may launch beneficial business combinations within their own and connected VCs' existing and prior portfolios, and mitigate problems stemming from both asymmetric information and the transaction costs associated with partner search.

Because VCs interact beneficially with the same VCs repeatedly, they want to maintain their good reputation within the network of connected VCs. VCs are interested in further collaboration, and therefore avoid undesirable behavior towards other connected VCs. Otherwise, they could fear that their prior friends will withhold future beneficial cooperation. Therefore, connected VCs are a wellsuited certification device (Hochberg et al., 2007, 2010). In addition, VCs want to attract promising, high-quality entrepreneurs. As high-quality entrepreneurs tend to match with high-quality VCs (Hsu, 2004; Sørensen, 2007), maintaining a good reputation is crucial for a high-quality deal flow. Consequently, a VC that gains a reputation as a reliable investor associated with beneficial business combinations is more likely to attract better deals and obtain a better position within its network. Portfolio companies financed by connected VCs thus enjoy more trust than companies coming from outside the network. In turn, adverse selection costs and uncertainties decrease. Additionally, connected VCs may limit misconduct in their portfolio companies. When the VCs still hold control rights in their portfolio companies, they may discipline companies' management and thus protect the counterparty from moral hazard and expropriation risks.

Consequently, we expect that prior ties among two VCs are associated with an increase in the probability that two companies from the portfolios of this VC pair will form a strategic alliance. We assume that the connected-VC-effect should be stronger when companies face greater information and transaction costs; that is, when the geographical and technological distances between two potential alliance partners increase.

This study focuses on strategic alliances of young biotech companies. From the theoretical perspective, there are at least two reasons why to focus on this industry. First, a typical biotechnology company faces a long product development cycle, usually 7 to 10 years, as the company advances from the first idea through clinical trials and the FDA approval process (Deeds et al., 1997). During this time, the outcome is uncertain, the company needs cash, and does not generate any revenue. Due to the long product development cycles and substantial financing needs, alliances often represent the major funding source for biotech companies and are therefore 
more important in this industry than in other industries.

Second, the above described agency problems and transaction costs are particularly pronounced in young biotech companies. In the first years of existence, biotech companies generally do not have enough experience to identify beneficial business combinations and appropriate collaboration partners. They typically do not enjoy large networks that they can tap to find these partners. In addition, they operate in highly risky and uncertain environment. From the viewpoint of the potential partner, the uncertainty regarding the future outcomes is substantial because young biotech companies usually do not have tangible assets but rather intangible assets. It is therefore difficult for potential partners to judge whether such a company will succeed in advancing products through the long development cycle to generate revenues. For young biotech companies this means that finding well-fitting and reliable strategic partners that are willing to invest is a challenging task. As young biotech companies develop new, potentially highly valuable products, they also face moral hazard and expropriation risks (Diestre and Rajagopalan, 2012; Rothaermel, 2001a, 2001b; Rothaermel and Deeds, 2004; Yang et al., 2014). Consequently, compared to more established companies or to companies from other sectors, biotech companies usually face larger agency as well as transaction costs (Baum et al., 2000; Robinson and Stuart, 2007a) and, consequently, can benefit more from tapping VC networks. Several papers that deal with strategic alliances also focus solely on the biotechnology industry (Lerner et al., 2003; Rothaermel, 2001a; Robinson and Stuart, 2007a).

\section{VC-backed biotech companies and their strategic alliances}

We consider the strategic alliances of young biotechnology companies. We extract information about all biotechnology companies founded between 2004 and 2008 in the US. To obtain this information, we combine the S\&P Capital IQ, Dow Jones VentureSource, and Thomson One VentureXpert databases. We rely on a cohort of companies from one country that are of a similar age and belong to one industry. Focusing on companies from one country, one industry, and of similar age reduces concerns of unobserved heterogeneity that could otherwise arise due to the firms' differing development stages and country or industry characteristics.

We collect data on all companies' strategic alliance activity between 2004 and 2019 from S\&P Capital IQ. S\&P Capital IQ defines strategic alliance as a "relationship between two or more companies to pursue a common objective through mutual cooperation, pooling of resources, etc." (https://www. capitaliq. com/). According to this definition, we count 1073 strategic alliances by our sample companies.

For all companies in our sample, we extract data on their VC financing (Dow Jones VentureSource, Thomson One VentureXpert, and S\&P Capital IQ), company characteristics (S\&P Capital IQ), and exits (S\&P Capital IQ, Dow Jones VentureSource, and Thomson One VentureXpert) until 2019.

Fig. 2 displays the geographical location of the 406 sample companies with strategic alliances. We observe clustering in a few US states, such as California, Massachusetts, and New Jersey.

Table 1, Panel A reports the descriptive statistics of the sample companies. At the time of the first alliance, the biotech companies are on average 5.79 years old (median is 5) and 63\% of them were VC-backed. The mean number of VC rounds is 2.30 (median is 2 ); they obtained financing from 4.8 different VC firms on average, $39 \%$ of them being foreign. Prior to their first investment in the biotech company, the involved VCs invested in 80 companies on average and have 272 total ties to other VC firms from prior syndicated investments. $^{2} 21 \%$ of the biotech companies from our sample reached an IPO exit.

Next, we turn to the strategic alliance partners of our sample companies. There are 778 unique strategic alliances partners. Fig. 3 displays their geographical location. Approximately 34\% of all partners are located outside the US, mostly in Western Europe.

For the strategic alliance partners, we also extract data on their VC financing and other company characteristics. Table 1, Panel B shows that at the time of their first strategic alliance, $23 \%$ of the strategic alliance partners in our dataset are VC-backed, with an average number of 2.87 rounds (median is 2). VC-backed strategic alliance partners usually have 3 VCs, $34 \%$ of the VCs are foreign VCs. Their VCs have more experience than VCs in the biotech sample on average, but they have weaker networks. However, these differences are not statistically significant. Strategic alliance partners are substantially older than the biotech companies are. Their median age is 19.5 years. Of the strategic alliance partners, $20.04 \%$ are from the biotechnology industry.

\section{Realized and counterfactual strategic alliances}

\subsection{Construction of the counterfactual alliances sample}

Alongside the sample of 1073 realized alliances, we build a sample of counterfactual (potential) alliances. To each realized alliance, we match six counterfactual alliances. The comparison between the sample of realized alliances and the sample of counterfactual alliances will help us in answering whether prior VC ties are beneficial for pairing companies from connected VCs' portfolios in an alliance. The counterfactual sample consists of combinations between biotech companies and strategic partners that were possible, but that never occurred. We run a random matching. By constructing the counterfactual sample, we focus on potential partners that have not been in a strategic alliance at the time of the realized alliance.

\footnotetext{
${ }^{2}$ We consider syndication at the VC-firm level, not at the VC-fund level.
} 


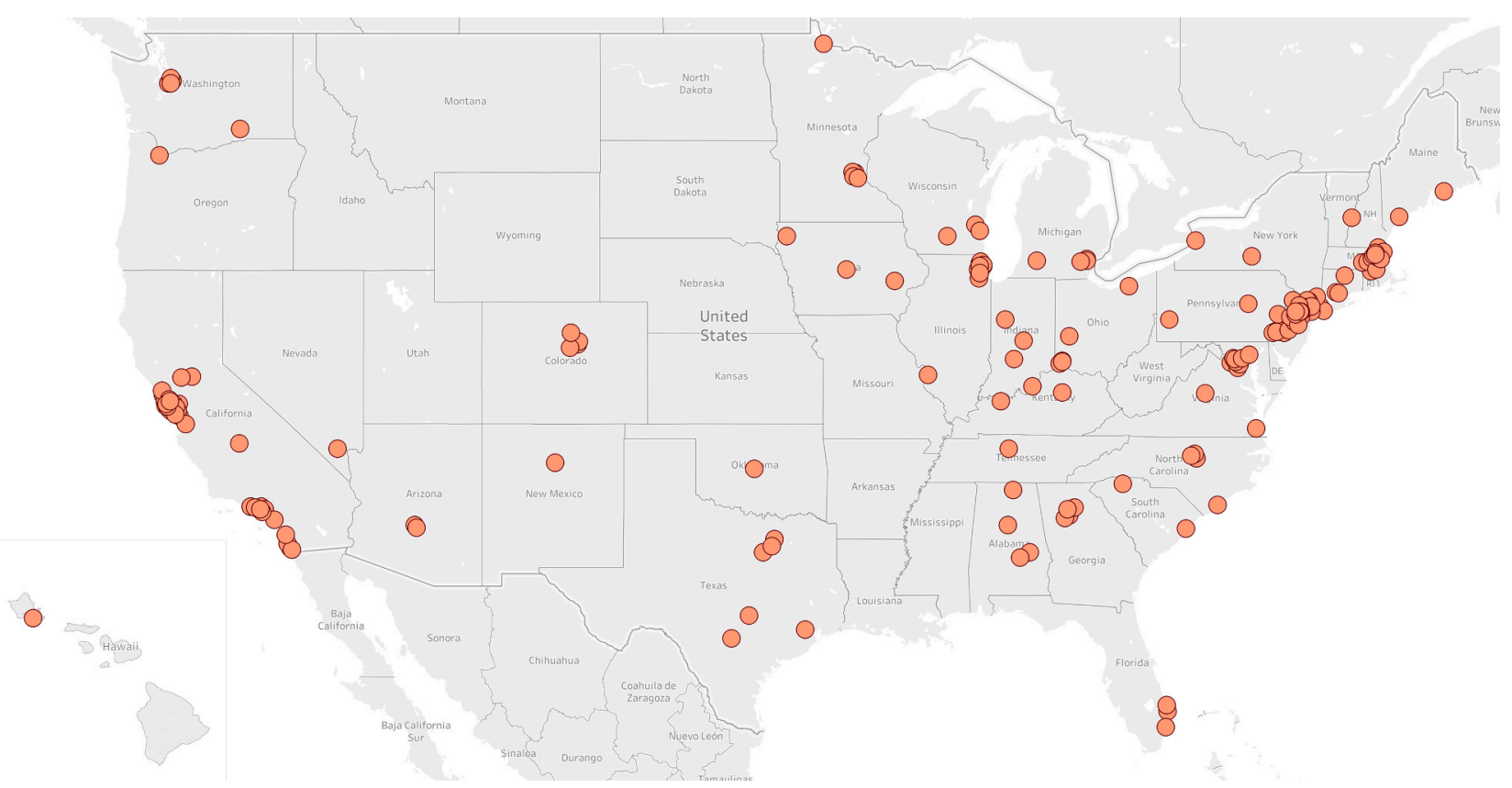

Fig. 2. Geographical location of biotech companies. 
Table 1

Descriptive statistics.

\begin{tabular}{|c|c|c|c|c|c|}
\hline \multicolumn{6}{|c|}{ Panel A: Biotech companies } \\
\hline & Mean & Median & Min & Max & Std. dev. \\
\hline Age & 5.79 & 5.00 & 0.00 & 15.00 & 3.22 \\
\hline VC dummy & 0.63 & 1.00 & 0.00 & 1.00 & - \\
\hline IPO dummy & 0.21 & 0.00 & 0.00 & 1.00 & - \\
\hline \multicolumn{6}{|c|}{ The following variables are calculated only for VC-backed biotech companies } \\
\hline VC rounds & 2.30 & 2.00 & 0.00 & 10.00 & 1.78 \\
\hline Investor count & 4.80 & 3.00 & 1.00 & 21.00 & 3.69 \\
\hline Foreign VCs & 0.39 & 0.30 & 0.00 & 1.00 & 0.49 \\
\hline VC experience & 79.55 & 56.45 & 0.00 & 312.33 & 60.46 \\
\hline Total VC ties & 271.91 & 220.70 & 0.00 & 1212.50 & 258.30 \\
\hline \multicolumn{6}{|c|}{ Panel B: Strategic alliance partners } \\
\hline & Mean & Median & Min & Max & Std. dev. \\
\hline Age & 40.38 & 19.50 & 0.00 & 449.00 & 54.33 \\
\hline VC dummy & 0.23 & 0.00 & 0.00 & 1.00 & - \\
\hline \multicolumn{6}{|c|}{ The following variables are calculated only for VC-backed strategic alliance partners } \\
\hline VC rounds & 2.87 & 2.00 & 1.00 & 24.00 & 2.42 \\
\hline Investor count & 4.55 & 3.00 & 1.00 & 40.00 & 4.91 \\
\hline Foreign VCs & 0.34 & 0.22 & 0.04 & 1.00 & 0.36 \\
\hline VC experience & 135.90 & 89.00 & 0.00 & 1087.00 & 182.27 \\
\hline Total VC ties & 210.82 & 147.00 & 0.00 & 1552.00 & 249.28 \\
\hline Biotech dummy & $20.04 \%$ & & & & \\
\hline
\end{tabular}

Legend: This table presents the descriptive statistics for the biotech companies and their strategic alliance partners. The statistics, except the IPO dummy, are calculated at the time of the biotech firm's first strategic alliance (Panel A) or at the time of the partner's first alliance (Panel B). Age represents the company age (in years). VC dummy is a binary variable that equals one if the company is VC-backed. VC rounds counts the number of VC investment rounds in the company. Investor count is the number of involved VCs. Foreign VCs is the fraction of non-US VCs. VC experience is the number of all prior portfolio companies of the involved VCs (average per VC). Total VC ties is the number of all prior syndicate partners of the involved VCs (average per VC). IPO dummy is a binary variable that equals one if the biotech company went public. Biotech dummy is a binary variable that equals one if the strategic alliance partner is a biotech company.

\subsection{Descriptive statistics for the realized and counterfactual alliances}

This section compares the characteristics of the realized and counterfactual alliances. We start by focusing on whether the two companies that formed (or potentially could have formed) an alliance are both VC-backed. If they are both VC-backed, we are interested in two specific cases, i.e. whether they share the same VC or whether they were financed by connected VCs. Table 2 shows that out of the 1073 realized strategic alliances, we have 382 pairs (35.6\%) in which only the biotech company was VC-backed, and 427 pairs (39.8\%) in which both partners were VC-backed. In the counterfactuals, we have 2524 matches (39.2\%) in which only the biotech is VC-backed and 2511 matches (39.0\%) in which both partners are VC-backed. The share of both-VC-backed pairs is not significantly different in the sample of realized and counterfactual alliances. We observe significant differences in the share of the same-VC-backed alliances, which is $4.85 \%$ for realized alliances and only $0.7 \%$ for the counterfactual alliances. Table 2 further reveals that the fraction of connected-VC-backed alliances differs between the samples of realized and counterfactual alliances. In $18.4 \%$ of realized alliances, but only in $7.4 \%$ of counterfactual alliances, connected VCs financed the alliance partners. The difference is statistically significant.

Besides using a dummy for connected VCs, we count the number of VC ties to capture the strength of the connection between the VCs that participate in the biotech company to those that finance the alliance partner. Imagine that we have three VCs in the biotech firm and three other VCs in the partner company. When we build all possible combinations between the biotech firm's VCs and the partner's VCs, we have nine VC-dyads. For each dyad, we count the number of all joint investments of these two VCs prior to the alliance closing date. Then, we summarize the ties for all nine dyads to obtain VC-dyad ties (sum). We thus count the sum of all prior joint investments that any of the VCs backing the biotech firm made with any of the VCs participating in the partner company. If no joint investments occurred in the past (or if the partner company is non-VC-backed), then the number of joint investments equals zero. The number of all prior joint ties amounts to almost 7 ties in the realized-alliances sample and around 4 ties in the counterfactualalliances sample on average, and the difference is statistically significant. We also depict the mean number of ties per VC-dyad. In the example above, we would divide the sum of the VC-dyad ties by 9. The mean number of ties per VC-dyad is significantly larger in realized sample than in the counterfactual alliances sample ( 0.12 and 0.07 , respectively). ${ }^{3}$ These variables suggest that bilateral ties between VCs, which result from prior joint investments, are important in improving access to potential alliance partners.

In the next step, we compare proxies for transaction and information costs between realized and counterfactual alliances. We focus on geographical distance between alliance partners as well as their technological distance. We expect that with increasing distance, the

\footnotetext{
${ }^{3}$ The mean is relatively small compared to the sum because the data are skewed. On the one hand, we observe many zeros and many small values, and on the other hand we find a few large syndicates of well-connected VCs.
} 


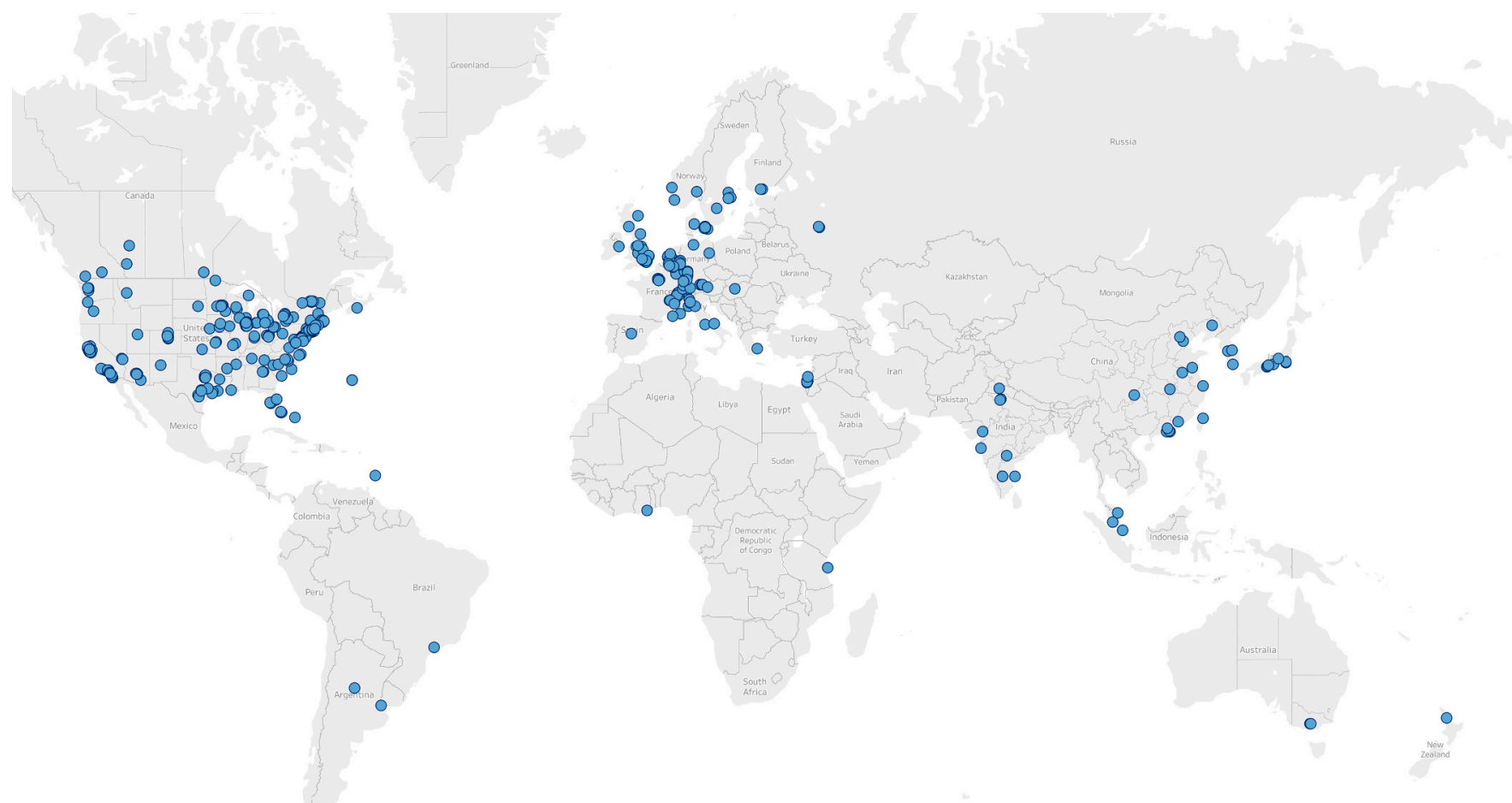

Fig. 3. Geographical location of strategic alliance partners. 
Table 2

Realized and counterfactual alliances.

\begin{tabular}{|c|c|c|c|c|c|c|c|c|c|c|c|c|}
\hline & Count & $\begin{array}{l}\text { Both non- } \\
\text { VC }\end{array}$ & $\begin{array}{l}\text { Both VC- } \\
\text { backed }\end{array}$ & $\begin{array}{l}\text { Biotech non- } \\
\text { VC/Partner VC }\end{array}$ & $\begin{array}{l}\text { Biotech VC/ } \\
\text { Partner non-VC }\end{array}$ & $\begin{array}{l}\text { Same-VC- } \\
\text { backed }\end{array}$ & $\begin{array}{l}\text { Connected-VC- } \\
\text { backed (dummy) }\end{array}$ & $\begin{array}{l}\text { VC-dyad ties } \\
\text { (sum) }\end{array}$ & $\begin{array}{l}\text { VC-dyad ties } \\
\text { (mean) }\end{array}$ & Distance & $\begin{array}{l}\text { Both } \\
\text { Biotech }\end{array}$ & $\begin{array}{l}\text { Age } \\
\text { difference }\end{array}$ \\
\hline $\begin{array}{l}\text { (1) Realized } \\
\text { alliances }\end{array}$ & 1073 & 159 & 427 & 105 & 382 & 52 & 197 & 6.88 & 0.12 & 4106 & 0.20 & 43.96 \\
\hline Percent & & $14.82 \%$ & $39.79 \%$ & $9.79 \%$ & $35.6 \%$ & $4.85 \%$ & $18.36 \%$ & & & & & \\
\hline $\begin{array}{l}\text { (2) Counter- } \\
\text { factual } \\
\text { alliances }\end{array}$ & 6438 & 890 & 2511 & 513 & 2524 & 42 & 476 & 4.20 & 0.07 & 4449 & 0.19 & 37.02 \\
\hline Percent & & $13.82 \%$ & $39.01 \%$ & $7.97 \%$ & $39.20 \%$ & $0.65 \%$ & $7.39 \%$ & & & & & \\
\hline$t$-value & & 0.050 & 0.162 & -1.267 & $3.115^{* * *}$ & $-11.540^{* * *}$ & $-11.749 * * *$ & $-2.869^{* * *}$ & -1.834 ** & $2.752^{* * *}$ & -1.010 & $-3.750^{\text {**** }}$ \\
\hline z-value & & 0.050 & 0.162 & -1.266 & $3.113^{* *}$ & $-11.440^{* * *}$ & $-11.643^{* * *}$ & $-2.173^{* *}$ & $-2.447^{* *}$ & $3.657^{* * *}$ & -1.010 & $-5.299^{* * * *}$ \\
\hline
\end{tabular}

Legend: Count is the number of realized and counterfactual alliances. Both non-VC is the number of alliances in which neither company is VC-backed. Both VC-backed counts the number of alliances in

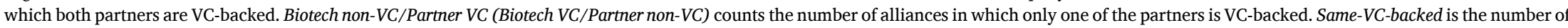

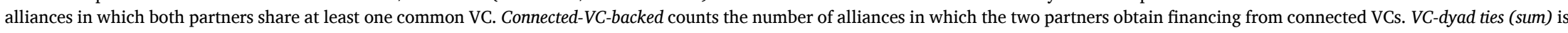
the sum of all ties (i.e., prior common investments) between the VCs in the biotech company and the VCs in the alliance partner. VC-dyad ties (mean) is the mean number (per VC-dyad) of ties between the VCs in the biotech company and the VCs in the alliance partner. Distance is the geographical distance between the alliance partners (in km). Both biotech is a binary variable that equals one if both alliance

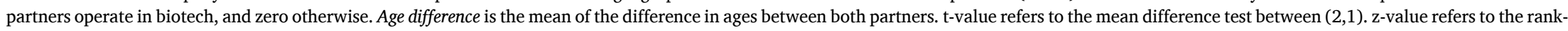
sum test. * **, and $* * *$ indicate statistical significance at the $10 \%, 5 \%$, and $1 \%$ levels, respectively. 
transaction and information costs of forming and maintaining an alliance increase. The biotech company is located at a distance of $4106 \mathrm{~km}$ from its partner on average in the sample of realized alliances. In the sample of counterfactual alliances, the geographical distance is significantly greater; it amounts to $4449 \mathrm{~km}$ on average. We do not find statistically significant differences in the technological distance. The share of partners from the biotech industry is $20 \%$ in the realized sample and $19 \%$ in the counterfactual sample.

\subsection{Endogeneity in syndicate formation}

So far, we have considered syndicate connections to be exogenous and we have focused on the question how these (prior) connections are related to the probability of alliance formation. If specific VC-dyad characteristics drive both the syndicate formation and the strategic alliance formation, our results may reflect spurious correlations. We address this issue by analyzing the potential determinants of syndicate formation, and especially of those syndicates with VCs with prior ties. We run a propensity score matching with a binary dependent variable that captures whether the involved VCs from a certain alliance pair (realized and counterfactuals) have an existing dyad connection (i.e., connected-VC-backed dummy). We include proxies for VC size, experience, and prior success. Our results from a Probit regression, which we show in Table 3, show that geographical distance between VCs is negatively associated with the probability of a syndicate formation. In addition, we find the following variables to be significantly and positively related to the existence of dyad connections: mean VC age, mean VC size (which we measure as the number of transactions), and the size of the VC syndicate. The explanatory power (R2) of the propensity score regression is $25 \%$. To those buckets of involved investors with a given probability of being a VC syndicate with prior ties, we match the five nearest neighbors of VC-buckets with a similar probability of being a syndicate with prior ties, but that are not part of a realized alliance. The average treatment effect of the connected-VC-backed dummy on the treated (ATT) is $\mathbf{1 7 . 2} \%$ for the treated subsample and $7.6 \%$ for the control subsample. The difference amounts to 9.6 percentage points and is highly statistically significant (with a t-value of 2.89). These values are similar to the values we observe in Table 2 where we compare our subsamples of realized and counterfactual alliances. Here, we observe $18.4 \%$ of realized alliances with connected VCs and 7.4\% of counterfactual alliances with connected VCs, the difference is 11.0 percentage points. Thus, we observe similar differences in the alliance formation independently of whether we control for the endogeneity in syndicate formation.

\section{VC-dyad ties and strategic alliances}

\subsection{VC-dyad ties and alliance partner match}

We analyze whether companies backed by two different VCs have a higher likelihood to pair in an alliance if these two VCs have mutual connections. More specifically, we investigate how the probability that a biotech company $i$ and a partner $j$ pair in an alliance is related to $i$ and $j$ having connected VCs. To deal with this probability, we first employ cross-sectional logit models within the sample of realized and counterfactual alliances. Second, we rely on conditional logit models in line with Bena and Li (2014). Our dependent variable is binary and takes the value one in the subsample of realized alliances; that is, when $i$ and $j$ pair in a strategic alliance. It equals zero in the subsample of counterfactual alliances. We expect the likelihood of pairing in a strategic alliance to increase when both

Table 3

Probit regression and two-step propensity score matching.

\begin{tabular}{|c|c|c|c|c|c|c|}
\hline \multirow[b]{3}{*}{ Syndicate } & \multirow{2}{*}{$\frac{\text { Step (1) }}{\text { DV: Prior Ties D }}$} & & \multicolumn{4}{|c|}{ Step (2) } \\
\hline & & & \multicolumn{4}{|c|}{ DV: Realized Alliance D } \\
\hline & Coefficients & & $\mathrm{T}$ & $\mathrm{C}$ & $\mathrm{D}$ & $t$-stat \\
\hline Age & $\begin{array}{l}0.0132 * \\
(0.0079)\end{array}$ & Unmatched & $17.2 \%$ & $11.2 \%$ & $6.1 \%$ & 2.57 \\
\hline Investments & $\begin{array}{l}0.0035^{* * *} \\
(0.0005)\end{array}$ & ATT & $17.2 \%$ & $7.6 \%$ & $9.6 \%$ & 2.89 \\
\hline Total Investors & $\begin{array}{l}0.1125^{* * *} \\
(0.0090)\end{array}$ & ATU & $11.2 \%$ & $19.0 \%$ & $7.8 \%$ & . \\
\hline IPOs & $\begin{array}{l}-0.0231 \\
(0.0201)\end{array}$ & ATE & & & $8.9 \%$ & . \\
\hline VC Distance & $\begin{array}{l}-0.0001^{* * *} \\
(0.0002)\end{array}$ & & & & & \\
\hline Log-Likelihood & -473.3058 & & & & & \\
\hline Pseudo $\mathrm{R}^{2}$ & 0.2512 & & & & & \\
\hline
\end{tabular}

Legend: This table shows the results from a propensity score matching. In Step (1) we include all realized and counterfactual alliances and the dependent variable is Prior Ties Dummy, which reflects whether any of the involved VCs on the one side of the alliance had prior ties with any of the VCs involved on the other side of the alliance. Syndicate Age is the average age of all involved VCs, Syndicate Investments is the average number of transactions per VC, Syndicate Total Investors is the total number of involved VCs, Syndicate IPOs is the total number of IPOs of involved VCs, Syndicate VC Distance is the average of the geographical distances between all possible combinations of the VCs. We present coefficients and robust standard errors in parentheses. *, **, and *** indicate statistical significance at the $10 \%, 5 \%$, and $1 \%$ levels, respectively. In Step (2), to each bucket of VCs that had a prior tie and are part of a realized alliance, we match another bucket of VCs that were not part of a realized alliance, but that have a similar probability of being a "prior ties VC bucket" (5 nearest neighbors). We compare the average treatment effects for the treated (ATT), untreated (ATU) and overall (ATE). T: Treated. C: Control. D: Difference. 
companies are backed by connected VCs.

To capture the effect of the specific VC-dyad and not the overall network effect, we control for the total VC ties. We also add VC similarity to proxy for the similarity in the degree of industry specialization of the VCs on both sides of the (potential) alliance. If both VCs have a similar degree of specialization, they will invest in similar companies, which, in turn, are more likely to form alliances with each other. Our VC similarity measure controls for this. To generate this measure, for each of the two partners in the strategic alliance, we first calculate the biotech / pharma specialization degree of the participating investors (at the time of each alliance its portfolio company is involved) as a fraction of all their combined investment rounds in biotech / pharma companies on their combined total investment rounds. In the second step, we take the absolute difference between the specialization value for the biotech and the strategic partner and multiply it by minus one. ${ }^{4}$

We control for VC-backing of the two partners. We further consider the geographical distance between them. To capture the technological distance, we add in indicator of whether the partner is from outside the biotech industry. We expect these distances to have a negative effect on the deal probability. We control whether the biotech company was involved in alliances in the past. We also add the age difference. We employ year dummies to account for time-specific effects. We show the correlations between these variables in Table 4.

Table 5, Panel A, presents the partial effects at the averages from the cross-sectional logit models; that is, the marginal effects of each variable when we include the covariates at their sample means. In column (1), the positive marginal effect on the binary variable Partner VC-backed suggests that the likelihood of forming an alliance increases when the potential strategic partner is VC-backed. We further see that an alliance is more likely to occur when the two VC-backed partners share the same VC than when they are financed by two different VCs. The probability is higher by 11.6 percentage points and the effect of the Same-VC-backed variable is significant at the $1 \%$ level. In columns $(2,3)$, we focus on the connected-VC-effect. In column (2), the number of all prior joint ties among VCs that financed the biotech firm and those that backed the alliance partner is positive and statistically significant at the $1 \%$ level. An increase in the VC-dyad ties by one standard deviation corresponds to an increase in the alliance probability by 2.3 percentage points. When we include the two variables (Same-VC-backed and VC-dyad ties) jointly in column (3), the latter effect remains similar, while the Same-VCbacked effect gets much smaller and loses its statistical significance.

We further conclude that the probability of pairing in an alliance decreases with increasing geographical distance between the partners. For technological distance, we do not observe a significant negative effect.

In columns $(4,5)$, we consider the time dimension. ${ }^{5}$ We first add a binary variable Prior ties old that equals one if the last joint investment of the connected VCs is older than one year. With this variable we want to investigate whether VCs that have more recent connections to each other have a stronger effect on building of strategic alliances between their portfolio companies. We use this variable in addition to the Connected-VC-backed dummy. The effect of the Connected-VC-backed dummy is highly statistically significant and positive, the effect of the Prior ties old dummy is highly statistically significant and negative. These results suggest that connectedVC-effect is centered in alliances in which VCs have recent joint investments. If the last syndication between connected VCs goes back further than one year, we do not observe a significant difference between shorter and longer periods (e.g., between two and five years). One potential reason is that we do not have many observations with "very old" links.

Second, we add variables that measure the time elapsed since the last investment into the biotech company, respectively its strategic partner. The aim is to analyze whether the VC effect is stronger in more recent investments. The shorter the time since last VC funding, the better the VC's information about the company. In addition, when a company is still in the VC's portfolio, the VC typically exerts strong control, which will have a disciplining effect on the company management not to engage in opportunistic behavior. We find a stronger effect for more recent investments. The effect is only significant for partner companies, but not for biotech companies. This is not surprising because we observe a low variation in this variable. Typically, our VC-backed biotech companies close their strategic alliances early, when they still are in the VC portfolio.

In column (6), we add a variable Future IPO as a control for the unobserved time-invariant quality of the company which might affect the results due to correlation between this variable and our ties measures. It does not show any significant effect. More important, it does not change the effects of other variables.

We repeat the regressions from Panel A in Table 5 with conditional logit models in line with Bena and Li (2014). As we employ fixed effects at the alliance level, all variables that do not vary at the alliance (and biotech company) level cannot be included because they are captured through these fixed effects. For this reason, we do not run the specification from column (6). We display the results in Panel B, but we only focus on the coefficients of interest and do not show the coefficients of the control variables. The results suggest

\footnotetext{
${ }^{4}$ Example 1: If all participating investors in the biotech have invested only in biotech/pharma, their biotech/pharma degree of specialization is $100 \%$. If all participating investors in the strategic partner have never participated in biotech/pharma, their specialization is $0 \%$. The difference is 100 , our similarity measure is thus -100 (minimum possible value, indicating the lowest possible similarity). Example 2 : In the portfolio of all participating investors (in the biotech company) we have a fraction of $60 \%$ investments in biotech/pharma. In the portfolio of all participating investors (in the strategic partner) we also have a fraction of $60 \%$ investments in biotech/pharma. The difference is 0 , our similarity measure is thus 0 (maximum possible value, indicating the greatest possible similarity).

${ }^{5}$ A natural solution seems to be to create a longitudinal dataset and run a hazard-rate model. We decided against this solution for two reasons. First, it would be a very challenging task (for the computational capacity) to create different samples of counterfactual alliances at different points in time and at each of these points to calculate the VC-related variables which would be necessary for a hazard rate model. We would, for example, have to find all ties between all pairs of participating VCs in all potential and realized strategic alliances at each point in time. Our second concern is that this exercise is probably not meaningful since the variation in our variables of interest over time is not large as VC-networks remain quite stable.
} 
Table 4

Correlation table.

\begin{tabular}{|c|c|c|c|c|c|c|c|c|c|c|c|c|c|c|c|c|c|}
\hline & & $\Xi$ & $\widehat{\mathcal{J}}$ & ल & $\mathcal{\Xi}$ & (1) & e & $E$ & $\Phi$ & $\widehat{\sigma}$ & $\stackrel{\stackrel{\partial}{\varrho}}{=}$ & $\widehat{\Xi}$ & $\stackrel{\overparen{\Xi}}{\Xi}$ & 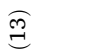 & $\stackrel{\mathcal{J}}{=}$ & $\stackrel{\mathscr{R}}{=}$ & $\stackrel{0}{=}$ \\
\hline (1) & Same-VC-backed & 1 & & & & & & & & & & & & & & & \\
\hline (2) & VC-dyad ties (sum) & $0.5267 *$ & 1 & & & & & & & & & & & & & & \\
\hline (3) & Connected-VC-backed & $0.3099^{*}$ & $0.6151 *$ & 1 & & & & & & & & & & & & & \\
\hline (4) & Total VC ties (sum) & $0.3193^{*}$ & $0.7914 *$ & $0.6632^{*}$ & 1 & & & & & & & & & & & & \\
\hline (5) & VC similarity (sum) & $-0.1996 *$ & $-0.5447^{*}$ & $-0.5233^{*}$ & $-0.7454 *$ & 1 & & & & & & & & & & & \\
\hline (6) & Biotech VC-backed & 0.0257 & $0.0527 *$ & $0.1033^{*}$ & $0.1100 *$ & $-0.1313^{*}$ & 1 & & & & & & & & & & \\
\hline (7) & Partner VC-backed & $0.0964 *$ & $0.2294 *$ & $0.3797^{*}$ & $0.2855^{*}$ & $-0.2726^{*}$ & 0.0055 & 1 & & & & & & & & & \\
\hline (8) & Both VC-backed & 0.0254 & $0.0642^{*}$ & $0.1329 *$ & $0.1407^{*}$ & $-0.1654 *$ & $0.7063^{*}$ & $0.1012^{*}$ & 1 & & & & & & & & \\
\hline (9) & Distance & $-0.0445^{*}$ & $-0.0730^{*}$ & $-0.0687^{*}$ & $-0.0493^{*}$ & $0.0414 *$ & 0.0145 & $-0.0298^{*}$ & 0.0052 & 1 & & & & & & & \\
\hline (10) & Partner not Biotech & $-0.1011^{*}$ & $-0.1864 *$ & $-0.2472^{*}$ & $-0.1661^{*}$ & $0.1318^{*}$ & -0.0082 & $-0.2295^{*}$ & $-0.0476^{*}$ & $0.0351 *$ & 1 & & & & & & \\
\hline (11) & Previous alliances & 0.0253 & $0.0537^{*}$ & $0.0677^{*}$ & $0.1337^{*}$ & $-0.1303^{*}$ & $0.2022^{*}$ & 0.0134 & $0.1167^{*}$ & 0.0037 & -0.0026 & 1 & & & & & \\
\hline (12) & Age difference & $-0.0471^{*}$ & $-0.0926^{*}$ & $-0.1434^{*}$ & $-0.1088^{*}$ & $0.0902^{*}$ & -0.0049 & $-0.0905^{*}$ & -0.0269 & -0.0018 & $0.2245^{*}$ & 0.0043 & 1 & & & & \\
\hline (13) & Prior ties old $(>1 y)$ & $0.0379 *$ & $0.1041^{*}$ & $0.6187^{*}$ & $0.2600^{*}$ & $-0.2451^{*}$ & $0.0632^{*}$ & $0.2264 *$ & $0.0924 *$ & -0.0235 & $-0.1139 *$ & $0.0655^{*}$ & $-0.0852^{*}$ & 1 & & & \\
\hline (14) & Days from last investment into biotech & $0.0480^{*}$ & $0.1044^{*}$ & $0.1500 *$ & $0.2134 *$ & $-0.2028^{*}$ & $0.5906^{*}$ & $0.0317^{*}$ & $0.3966^{*}$ & 0.0062 & -0.0164 & 0.3340 * & 0.0032 & $0.0966^{*}$ & 1 & & \\
\hline (15) & Days from last investment into partner & $0.1486^{*}$ & $0.3082^{*}$ & $0.5131 *$ & $0.3633^{*}$ & $-0.3260^{*}$ & -0.0053 & $0.7207^{*}$ & $0.1112^{*}$ & $-0.0677^{*}$ & $-0.3355^{*}$ & 0.0285 & $-0.2170^{*}$ & $0.3298^{*}$ & $0.0350 *$ & 1 & \\
\hline (16) & Future IPO & $0.0516 *$ & $0.1438 *$ & $0.1522^{*}$ & $0.2988^{*}$ & $-0.2886^{*}$ & $0.2075^{*}$ & $0.0559^{*}$ & $0.2336^{*}$ & -0.0095 & -0.0262 & $0.1996 *$ & -0.0158 & $0.0878^{*}$ & $0.3514 *$ & $0.0598^{*}$ & 1 \\
\hline
\end{tabular}

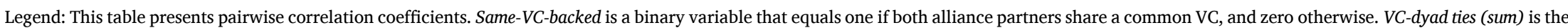

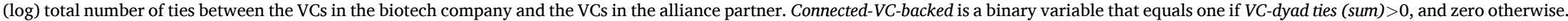

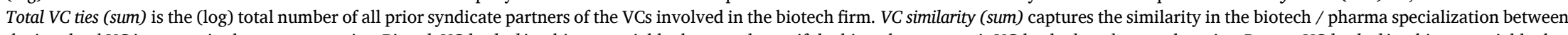

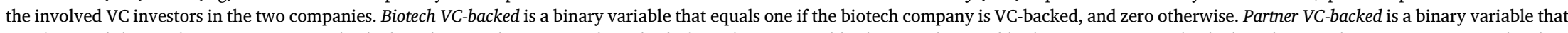

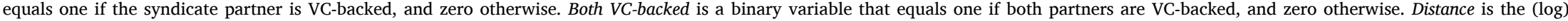

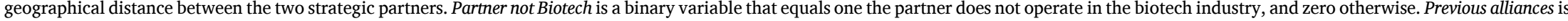

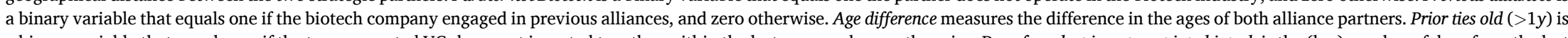

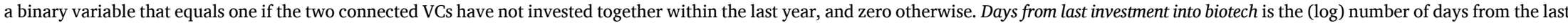

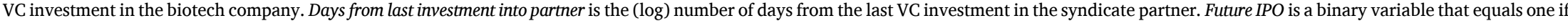
the company goes public, and zero otherwise. * indicate statistical significance at the $1 \%$ level. 
Table 5

Logit and clogit regressions: realized and counterfactual alliances.

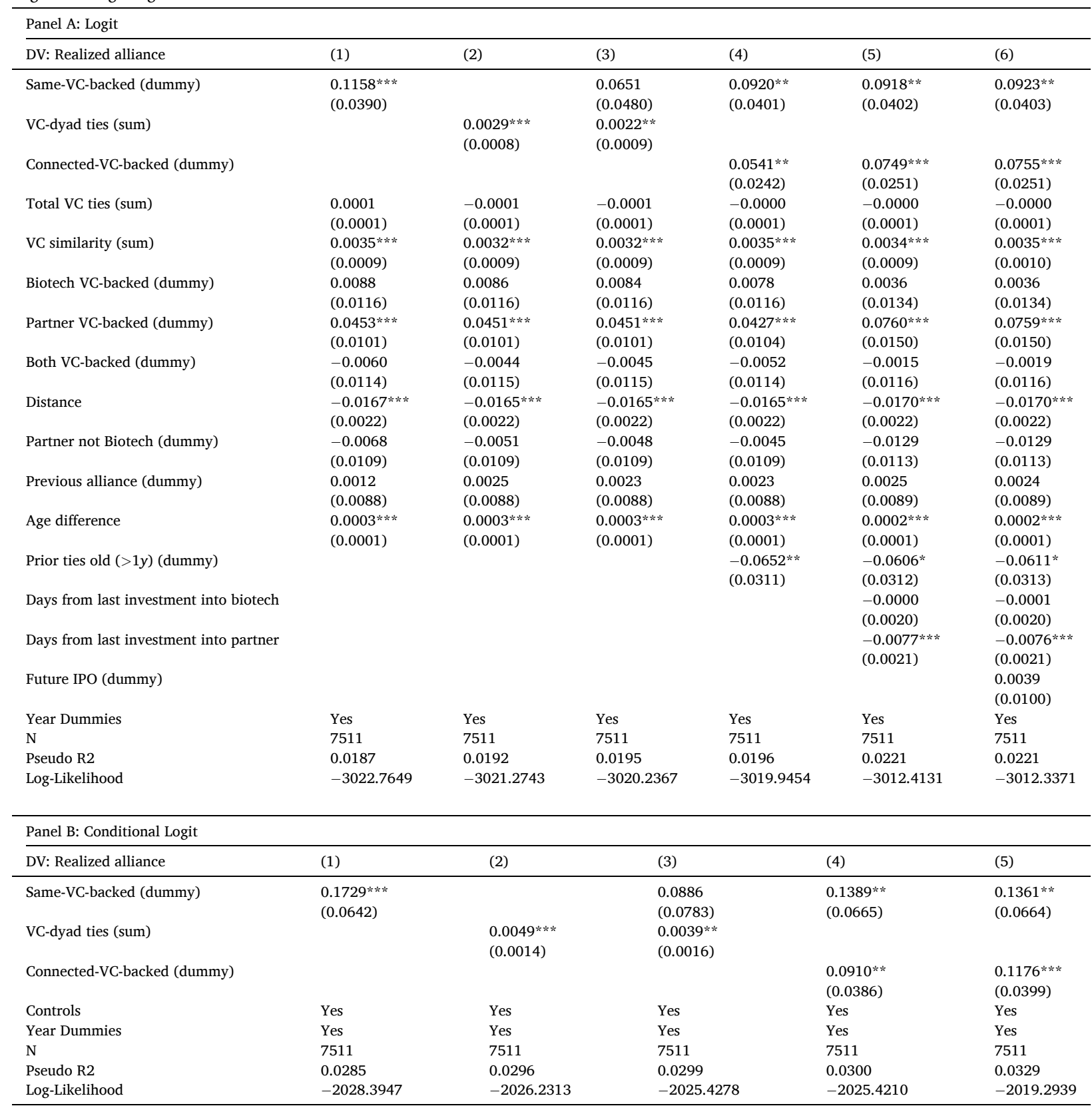

Legend: This table presents the partial effects at the averages from the Logit (Panel A) and Conditional Logit (Panel B) regressions with the dependent variable realized alliance, which is a dummy variable that equals one if an alliance was realized, and zero for counterfactual alliances. Same-VC-backed is a binary variable that equals one if both alliance partners share a common VC, and zero otherwise. VC-dyad ties (sum) is the (log) total number of ties between the VCs in the biotech company and the VCs in the alliance partner. Connected-VC-backed is a binary variable that equals one if VC-dyad ties (sum) $>0$, and zero otherwise. Total VC ties (sum) is the (log) total number of all prior syndicate partners of the VCs involved in the biotech firm. VC similarity (sum) captures the similarity in the biotech / pharma specialization between the involved VC investors in the two companies. Biotech VCbacked is a binary variable that equals one if the biotech company is VC-backed, and zero otherwise. Partner VC-backed is a binary variable that equals one if the syndicate partner is VC-backed, and zero otherwise. Both VC-backed is a binary variable that equals one if both partners are VC-backed, and zero otherwise. Distance is the (log) geographical distance between the two strategic partners. Partner not Biotech is a binary variable that equals one the partner does not operate in the biotech industry, and zero otherwise. Previous alliances is a binary variable that equals one if the biotech company engaged in previous alliances, and zero otherwise. Age difference measures the difference in the ages of both alliance partners. Prior ties old ( $>1 y$ ) is a binary variable that equals one if the two connected VCs have not invested together within the last year, and zero otherwise. Days from last investment into biotech is the (log) number of days from the last VC investment in the biotech company. Days from last investment into partner is the (log) number of days from the last VC investment in the syndicate partner. Future IPO is a binary variable that equals one if the company goes public, and zero 
otherwise. A constant is included in all regressions. Robust standard errors are displayed in parentheses. *, **, and *** indicate statistical significance at the $10 \%, 5 \%$, and $1 \%$ levels, respectively.

that all the effects stay at the same level of statistical significance. Their magnitudes are slightly higher. We thus conclude that the results are not driven by unobserved time-invariant firm-specific characteristics.

\subsection{VC-dyad ties and transaction and information costs}

So far, we have concluded that VC ties and their intensity are beneficial to alliance formation between portfolio companies of connected VCs. In the next step, we analyze whether VC ties are more beneficial when transaction and information costs increase. To proxy for transaction and information costs, we employ geographical and technological distance. Other things being equal, the greater these distances are between two companies, the greater the transaction and information costs of pairing in an alliance are. To measure the connected-VC-effect at different levels of transaction and information costs, we include interaction terms between the two distance measures and our connected-VC measures. Consistently with the prior analysis, we are also interested in the same-VC-effect and we include the interaction terms of the distance measures with the same-VC-backed dummy.

Table 6 shows that same-VC-backing is beneficial in mitigating geographical distances. ${ }^{6}$ The interaction term in column (1) has a positive sign and is statistically significant, supporting the view that the negative distance effect disappears when both partners share the same VC. We find a statistically significant effect for connected VCs in column (3), but not in column (5).

As to the technological distance, we find that the probability that two companies from different industries pair in an alliance increases when these companies were financed by the same VC or by VCs with ties. This effect holds for both of our alternative variables (see columns $(4,6)$ ). Typically, larger information asymmetries will accompany diversified alliances compared to focused alliances, but connected VCs seem to be able to reduce these asymmetries. Connected VCs thus help their portfolio companies overcome technological distance and enable them to better diversify into other sectors.

\subsection{VC-dyad ties and IPO exit}

Finally, we want to link the different alliance types to the likelihood of an IPO exit. The results in Table 7 suggest that companies with alliance partners from connected VCs' portfolios realize IPOs more often than other companies do. Column (2) suggests that having at least one alliance with a partner from a connected VC's portfolio increases the likelihood of an IPO by 26.5 percentage points. For comparison, having at least one alliance with a same-VC-backed partner is associated with a 14.8 percentage point increase, as column (1) shows. Furthermore, we check these results for robustness by altering the variables of interest. In column (3), we replace the same-VC-dummy by a variable that counts the number of common VCs in the alliance pair. When we increase this same-VCvariable by one standard deviation, the IPO probability increases by 11.9 percentage points. In column (4), we replace the connected-VC-backed dummy variable with the sum of all VC-dyad ties between VCs in the biotech company and the VCs in the alliance partner. A one-standard-deviation increase in the VC-dyad ties (sum) is associated with a 32.3 percentage point higher IPO probability. In addition, in columns $(5,6)$, we replace the sum measures from columns $(3,4)$ with average-per-alliance measures. We again find positive and statistically significant effects.

We then estimate two models in which we include the same-VC and connected-VC measures jointly. In column (7), we include the same-VC-backed dummy together with the sum of all VC-dyad ties between VCs in the biotech company and the VCs in the alliance partner. The same-VC-backed marginal effect becomes statistically insignificant, while the marginal effect of the VC-dyad ties stays statistically significant. In column (8), we employ the same-VC-backed dummy and the mean VC-dyad ties. The results again show that the same-VC-backed variable becomes statistically insignificant, while the average VC-dyad ties variable remains statistically significant.

These results indicate that alliances between the portfolio companies of connected VCs are associated with more successful companies.

\section{Conclusion}

This study advances our knowledge of how networks between financial intermediaries contribute to companies' development. We are the first to analyze how VC networks, grounded in prior bilateral cooperations between these investors, facilitate cooperation between portfolio companies from connected VCs' portfolios. By tracing individual VCs' investment and syndication histories, our analyses suggest that two companies whose VCs invested together in the past are more likely to enter a strategic alliance than other company pairs. We argue that VCs may be able to identify potential benefits from cooperation that might otherwise stay undetected because they have specific and detailed knowledge of the companies in their portfolios and they share this knowledge with their connected peers. Thus, they help reduce the search and transaction costs. We also suggest that for VCs and their portfolio companies, connected VCs may serve as a certification device that mitigates the information problems between involved alliance partners. Connected VCs may also mitigate moral hazard and expropriation risks. Our results support the conclusion that connected VCs are

\footnotetext{
${ }^{6}$ We run OLS regressions because the interpretation of the coefficients on interaction terms in non-linear models in not straightforward (Ai and Norton, 2003; Williams, 2009).
} 
Table 6

OLS regressions with realized and counterfactual alliances (interaction effects).

\begin{tabular}{|c|c|c|c|c|c|c|}
\hline DV: Realized alliance & (1) & $(2)$ & (3) & (4) & (5) & (6) \\
\hline Same-VC-backed (dummy) & $\begin{array}{l}0.0992 \\
(0.1883)\end{array}$ & $\begin{array}{l}0.3190 * * * \\
(0.0731)\end{array}$ & & & & \\
\hline VC-dyad ties (sum) & & & $\begin{array}{l}0.0021 \\
(0.0028)\end{array}$ & $\begin{array}{l}0.0046^{* * *} \\
(0.0012)\end{array}$ & & \\
\hline Connected-VC (dummy) & & & & & $\begin{array}{l}0.2414 * * * \\
(0.0734)\end{array}$ & $\begin{array}{l}0.2861^{* * *} \\
(0.0335)\end{array}$ \\
\hline Total VC ties (sum) & $\begin{array}{l}-0.0000 \\
(0.0001)\end{array}$ & $\begin{array}{l}0.0000 \\
(0.0001)\end{array}$ & $\begin{array}{l}-0.0002^{* *} \\
(0.0001)\end{array}$ & $\begin{array}{l}-0.0002^{*} \\
(0.0001)\end{array}$ & $\begin{array}{l}-0.0003^{* * *} \\
(0.0001)\end{array}$ & $\begin{array}{l}-0.0002^{* * *} \\
(0.0001)\end{array}$ \\
\hline VC similarity (sum) & $\begin{array}{l}0.0025^{* * *} \\
(0.0007)\end{array}$ & $\begin{array}{l}0.0027^{* * *} \\
(0.0008)\end{array}$ & $\begin{array}{l}0.0031^{* * *} \\
(0.0008)\end{array}$ & $\begin{array}{l}0.0037^{* * *} \\
(0.0009)\end{array}$ & $\begin{array}{l}0.0031 * * * \\
(0.0008)\end{array}$ & $\begin{array}{l}0.0034^{* * *} \\
(0.0008)\end{array}$ \\
\hline Biotech VC-backed (dummy) & $\begin{array}{l}0.0042 \\
(0.0133)\end{array}$ & $\begin{array}{l}0.0064 \\
(0.0137)\end{array}$ & $\begin{array}{l}0.0033 \\
(0.0134)\end{array}$ & $\begin{array}{l}0.0049 \\
(0.0133)\end{array}$ & $\begin{array}{l}-0.0009 \\
(0.0133)\end{array}$ & $\begin{array}{l}0.0001 \\
(0.0133)\end{array}$ \\
\hline Partner VC-backed (dummy) & $\begin{array}{l}0.0676^{* * *} \\
(0.0147)\end{array}$ & $\begin{array}{l}0.0673 * * * \\
(0.0147)\end{array}$ & $\begin{array}{l}0.0611^{* * *} \\
(0.0145)\end{array}$ & $\begin{array}{l}0.0577^{* * *} \\
(0.0144)\end{array}$ & $\begin{array}{l}0.0431 * * * \\
(0.0137)\end{array}$ & $\begin{array}{l}0.0404^{* * *} \\
(0.0137)\end{array}$ \\
\hline Both VC-backed (dummy) & $\begin{array}{l}-0.0025 \\
(0.0116)\end{array}$ & $\begin{array}{l}-0.0032 \\
(0.0118)\end{array}$ & $\begin{array}{l}-0.0022 \\
(0.0117)\end{array}$ & $\begin{array}{l}-0.0031 \\
(0.0117)\end{array}$ & $\begin{array}{l}-0.0053 \\
(0.0116)\end{array}$ & $\begin{array}{l}-0.0057 \\
(0.0116)\end{array}$ \\
\hline Distance & $\begin{array}{l}-0.0212^{* * *} \\
(0.0031)\end{array}$ & $\begin{array}{l}-0.0189 * * * \\
(0.0030)\end{array}$ & $\begin{array}{l}-0.0216^{* * *} \\
(0.0032)\end{array}$ & $\begin{array}{l}-0.0203^{* * *} \\
(0.0031)\end{array}$ & $\begin{array}{l}-0.0208 * * * \\
(0.0032)\end{array}$ & $\begin{array}{l}-0.0191 * * * \\
(0.0031)\end{array}$ \\
\hline Partner not Biotech (dummy) & $\begin{array}{l}-0.0116 \\
(0.0108)\end{array}$ & $\begin{array}{l}-0.0116 \\
(0.0109)\end{array}$ & $\begin{array}{l}-0.0086 \\
(0.0109)\end{array}$ & $\begin{array}{l}-0.0190 * \\
(0.0111)\end{array}$ & $\begin{array}{l}-0.0009 \\
(0.0109)\end{array}$ & $\begin{array}{l}-0.0154 \\
(0.0114)\end{array}$ \\
\hline $\begin{array}{l}\text { Same-VC-backed } \\
\mathrm{x} \text { Distance }\end{array}$ & $\begin{array}{l}0.0438 * \\
(0.0241)\end{array}$ & & & & & \\
\hline $\begin{array}{l}\text { Same-VC-backed } \\
\text { x Partner not Biotech (dummy) }\end{array}$ & & $\begin{array}{l}0.2112^{* *} \\
(0.0968)\end{array}$ & & & & \\
\hline $\begin{array}{l}\text { VC-dyad ties (sum) } \\
\text { x Distance }\end{array}$ & & & $\begin{array}{l}0.0006 * \\
(0.0004)\end{array}$ & & & \\
\hline $\begin{array}{l}\text { VC-dyad ties (sum) } \\
\text { x Partner not Biotech (dummy) }\end{array}$ & & & & $\begin{array}{l}0.0045^{* * *} \\
(0.0016)\end{array}$ & & \\
\hline $\begin{array}{l}\text { Connected-VC (dummy) } \\
\text { x Distance }\end{array}$ & & & & & $\begin{array}{l}0.0141 \\
(0.0092)\end{array}$ & \\
\hline $\begin{array}{l}\text { Connected-VC (dummy) } \\
\text { x Partner not Biotech (dummy) }\end{array}$ & & & & & & $\begin{array}{l}0.0986^{* * *} \\
(0.0340)\end{array}$ \\
\hline Previous alliance (dummy) & $\begin{array}{l}0.0016 \\
(0.0087)\end{array}$ & $\begin{array}{l}0.0000 \\
(0.0090)\end{array}$ & $\begin{array}{l}0.0024 \\
(0.0087)\end{array}$ & $\begin{array}{l}0.0019 \\
(0.0087)\end{array}$ & $\begin{array}{l}0.0044 \\
(0.0086)\end{array}$ & $\begin{array}{l}0.0039 \\
(0.0086)\end{array}$ \\
\hline Age difference & $\begin{array}{l}0.0002^{* * *} \\
(0.0001)\end{array}$ & $\begin{array}{l}0.0002^{* * *} \\
(0.0001)\end{array}$ & $\begin{array}{l}0.0002^{* * *} \\
(0.0001)\end{array}$ & $\begin{array}{l}0.0002^{* * *} \\
(0.0001)\end{array}$ & $\begin{array}{l}0.0002 * * * \\
(0.0001)\end{array}$ & $\begin{array}{l}0.0002^{* * *} \\
(0.0001)\end{array}$ \\
\hline Prior ties old ( $>1 y$ ) (dummy) & $\begin{array}{l}-0.0097 \\
(0.0237)\end{array}$ & $\begin{array}{l}-0.0078 \\
(0.0240)\end{array}$ & $\begin{array}{l}0.0057 \\
(0.0245)\end{array}$ & $\begin{array}{l}0.0046 \\
(0.0249)\end{array}$ & $\begin{array}{l}-0.2321^{* * *} \\
(0.0333)\end{array}$ & $\begin{array}{l}-0.2293^{* * *} \\
(0.0336)\end{array}$ \\
\hline Days from last investment into biotech & $\begin{array}{l}-0.0001 \\
(0.0019)\end{array}$ & $\begin{array}{l}0.0000 \\
(0.0020)\end{array}$ & $\begin{array}{l}0.0004 \\
(0.0019)\end{array}$ & $\begin{array}{l}0.0004 \\
(0.0019)\end{array}$ & $\begin{array}{l}-0.0004 \\
(0.0019)\end{array}$ & $\begin{array}{l}-0.0004 \\
(0.0019)\end{array}$ \\
\hline Days from last investment into partner & $\begin{array}{l}-0.0066^{* * *} \\
(0.0022)\end{array}$ & $\begin{array}{l}-0.0062^{* * *} \\
(0.0022)\end{array}$ & $\begin{array}{l}-0.0059 * * * \\
(0.0022)\end{array}$ & $\begin{array}{l}-0.0053^{* *} \\
(0.0022)\end{array}$ & $\begin{array}{l}-0.0082^{* * *} \\
(0.0021)\end{array}$ & $\begin{array}{l}-0.0078^{* * *} \\
(0.0021)\end{array}$ \\
\hline Future IPO (dummy) & $\begin{array}{l}0.0014 \\
(0.0093)\end{array}$ & $\begin{array}{l}0.0029 \\
(0.0099)\end{array}$ & $\begin{array}{l}0.0042 \\
(0.0094)\end{array}$ & $\begin{array}{l}0.0053 \\
(0.0094)\end{array}$ & $\begin{array}{l}0.0050 \\
(0.0092)\end{array}$ & $\begin{array}{l}0.0050 \\
(0.0092)\end{array}$ \\
\hline Year Dummies & Yes & Yes & Yes & Yes & Yes & Yes \\
\hline $\mathrm{N}$ & 7511 & 7511 & 7511 & 7511 & 7511 & 7511 \\
\hline Adj. R2 & 0.1705 & 0.1679 & 0.1667 & 0.1681 & 0.1861 & 0.1870 \\
\hline F-value & 84.6113 & 42.5105 & 81.7687 & 81.8060 & 88.4678 & 89.2276 \\
\hline$p$-value & 0.0000 & 0.0000 & 0.0000 & 0.0000 & 0.0000 & 0.0000 \\
\hline
\end{tabular}

Legend: This table presents the results of the OLS regressions with interaction effects. The dependent variable is realized alliance, which is a binary variable that equals one if an alliance was realized, and zero for counterfactual alliances. Same-VC-backed is a binary variable that equals one if both alliance partners share a common VC, and zero otherwise. VC-dyad ties (sum) is the (log) total number of ties between the VCs in the biotech company and the VCs in the alliance partner. Connected-VC-backed is a binary variable that equals one if VC-dyad ties (sum) $>0$, and zero otherwise. Total VC ties (sum) is the (log) total number of all prior syndicate partners of the VCs involved in the biotech firm. VC similarity (sum) captures the similarity in the biotech / pharma specialization between the involved VC investors in the two companies. Biotech VC-backed is a binary variable that equals one if the biotech company is VC-backed, and zero otherwise. Partner VC-backed is a binary variable that equals one if the syndicate partner is VC-backed, and zero otherwise. Both VC-backed is a binary variable that equals one if both partners are VC-backed, and zero otherwise. Distance is the (log) geographical distance between the two strategic partners. Partner not Biotech is a binary variable that equals one the partner does not operate in the biotech industry, and zero otherwise. Previous alliances is a binary variable that equals one if the biotech company engaged in previous alliances, and zero otherwise. Age difference measures the difference in the ages of both alliance partners. Prior ties old ( $>1 y)$ is a binary variable that equals one if the two connected VCs have not invested together within the last year, and zero otherwise. Days from last investment into biotech is the (log) number of days from the last VC investment in the biotech company. Days from last investment into partner is the (log) number of days from the last VC investment in the syndicate partner. Future IPO is a binary variable that equals one if the company goes public, and zero otherwise. In addition, we include year dummies and a constant in all regressions. Robust standard errors are displayed in parentheses. *, ***, and *** indicate statistical significance at the $10 \%, 5 \%$, and $1 \%$ levels, respectively. 
Table 7

Logistic regressions with company exits.

\begin{tabular}{|c|c|c|c|c|c|c|c|c|}
\hline DV: IPO dummy & (1) & $(2)$ & (3) & (4) & (5) & $(6)$ & (7) & (8) \\
\hline Biotech VC-backed (dummy) & $\begin{array}{l}0.0760 \\
(0.0818)\end{array}$ & $\begin{array}{l}-0.0722 \\
(0.0714)\end{array}$ & $\begin{array}{l}0.0907 \\
(0.0781)\end{array}$ & $\begin{array}{l}0.0209 \\
(0.0891)\end{array}$ & $\begin{array}{l}0.0580 \\
(0.0813)\end{array}$ & $\begin{array}{l}0.0202 \\
(0.0818)\end{array}$ & $\begin{array}{l}0.0228 \\
(0.0897)\end{array}$ & $\begin{array}{l}0.0207 \\
(0.0815)\end{array}$ \\
\hline Partner VC-backed (dummy) & $\begin{array}{l}0.1924 \\
(0.1532)\end{array}$ & $\begin{array}{l}0.1869 \\
(0.1410)\end{array}$ & $\begin{array}{l}0.1989 \\
(0.1542)\end{array}$ & $\begin{array}{l}0.1993 \\
(0.1582)\end{array}$ & $\begin{array}{l}0.1969 \\
(0.1543)\end{array}$ & $\begin{array}{l}0.1976 \\
(0.1556)\end{array}$ & $\begin{array}{l}0.2017 \\
(0.1588)\end{array}$ & $\begin{array}{l}0.1939 \\
(0.1550)\end{array}$ \\
\hline Both VC-backed (dummy) & $\begin{array}{l}0.0378 \\
(0.0791)\end{array}$ & $\begin{array}{l}0.0581 \\
(0.0624)\end{array}$ & $\begin{array}{l}0.0344 \\
(0.0746)\end{array}$ & $\begin{array}{l}0.0756 \\
(0.0814)\end{array}$ & $\begin{array}{l}0.0494 \\
(0.0785)\end{array}$ & $\begin{array}{l}0.0538 \\
(0.0749)\end{array}$ & $\begin{array}{l}0.0751 \\
(0.0814)\end{array}$ & $\begin{array}{l}0.0550 \\
(0.0755)\end{array}$ \\
\hline Same-VC-backed (dummy) & $\begin{array}{l}0.1481 * * \\
(0.0699)\end{array}$ & & & & & & $\begin{array}{l}-0.0387 \\
(0.0990)\end{array}$ & $\begin{array}{l}0.0407 \\
(0.0751)\end{array}$ \\
\hline Connected-VC-backed (dummy) & & $\begin{array}{l}0.2649 * * * \\
(0.0474)\end{array}$ & & & & & & \\
\hline Same-VC-backed (sum) & & & $\begin{array}{l}0.0011^{* * *} \\
(0.0004)\end{array}$ & & & & & \\
\hline VC-dyad ties (sum) & & & & $\begin{array}{l}0.0021^{* * *} \\
(0.0008)\end{array}$ & & & $\begin{array}{l}0.0022^{* * *} \\
(0.0009)\end{array}$ & \\
\hline Same-VC-backed (mean) & & & & & $\begin{array}{l}0.6488^{* * *} \\
(0.2334)\end{array}$ & & & \\
\hline VC-dyad ties (mean) & & & & & & $\begin{array}{l}0.3574 * * * \\
(0.1127)\end{array}$ & & $\begin{array}{l}0.3288^{* * *} \\
(0.1206)\end{array}$ \\
\hline Foreign VCs (dummy) & $\begin{array}{l}0.0007^{* * * *} \\
(0.0002)\end{array}$ & $\begin{array}{l}0.0005^{* * *} \\
(0.0002)\end{array}$ & $\begin{array}{l}0.0006 * * * \\
(0.0002)\end{array}$ & $\begin{array}{l}0.0004 \\
(0.0003)\end{array}$ & $\begin{array}{l}0.0007^{* * *} \\
(0.0002)\end{array}$ & $\begin{array}{l}0.0007^{* * *} \\
(0.0002)\end{array}$ & $\begin{array}{l}0.0004 \\
(0.0003)\end{array}$ & $\begin{array}{l}0.0007^{* * *} \\
(0.0002)\end{array}$ \\
\hline Alliance count (sum) & $\begin{array}{l}0.0579 \\
(0.0415)\end{array}$ & $\begin{array}{l}0.0297 \\
(0.0363)\end{array}$ & $\begin{array}{l}0.0357 \\
(0.0468)\end{array}$ & $\begin{array}{l}-0.0541 \\
(0.0601)\end{array}$ & $\begin{array}{l}0.0712^{*} \\
(0.0396)\end{array}$ & $\begin{array}{l}0.0631 \\
(0.0401)\end{array}$ & $\begin{array}{l}-0.0546 \\
(0.0600)\end{array}$ & $\begin{array}{l}0.0587 \\
(0.0404)\end{array}$ \\
\hline $\mathrm{N}$ & 406 & 406 & 406 & 406 & 406 & 406 & 406 & 406 \\
\hline Pseudo R2 & 0.1793 & 0.2367 & 0.2017 & 0.2581 & 0.1866 & 0.2046 & 0.2587 & 0.2055 \\
\hline Log-Likelihood & -173.1344 & -161.0194 & -168.4078 & -156.4931 & -171.5775 & -167.7877 & -156.3705 & -167.5910 \\
\hline
\end{tabular}

Legend: This table presents the partial effects at the averages from the logistic regressions with the dependent variable IPO dummy, which equals one if the company went public, and zero otherwise. Biotech VC-backed is a binary variable that equals one if the biotech company is VC-backed, and zero otherwise. Partner VC-backed is a binary variable that equals one if the biotech company had at least one alliance with a partner that was VC-backed, and zero otherwise. Both VC-backed is a binary variable that equals one if the VC-backed biotech company had at least one alliance with a partner that was VC-backed, and zero otherwise. Same-VC-backed is a binary variable that equals one if there was at least one common VC in the biotech company and any of its strategic alliance partners, and zero otherwise. Connected-VC-backed is a binary variable that equals one if the company had at least one alliance in which both partners obtained financing from connected VCs (i.e., had prior common investments), and zero otherwise. Same-VC-backed (sum) and Same-VC-backed (mean) represent the sum or mean of the Same-VC-backed (dummy) over all realized alliances of the biotech company. VCdyad ties (sum) and VC-dyad ties (mean) represent the (log) sum or mean of all ties (i.e., prior common investments) between the VCs in the biotech company and the VCs in the alliance partners. Foreign VCs is a binary variable that equals one if there was at least one non-US VCs involved in the biotech firm. Alliance count (sum) is the (log) number of all alliances of the biotech firm. A constant is included in all regressions. Robust standard errors are displayed in parentheses. *, **, and ${ }^{* * *}$ indicate statistical significance at the $10 \%, 5 \%$, and $1 \%$ levels, respectively.

particularly beneficial when transaction and information costs are large. More specifically, the positive connected-VC-effect increases when geographical and technological distances become greater. Finally, we show that VC-backed companies that pair in alliances with partners financed by connected VCs realize IPOs more often. Our study thus documents a new channel through which portfolio companies benefit from ties among VCs.

Our research has implications for the academic debate on alliance formation and factors that facilitate it. The results on the value that syndication networks may generate are relevant for industry participants as well. For example, for entrepreneurs who select which VCs to tap for financing, our results stress the benefits that VC ties towards other VCs have. We advise entrepreneurs to take a careful look at the VC syndication networks and connected VCs' prior and existing portfolios when selecting their investors.

A topic that deserves a deeper investigation is how the connected-VC-effect changes when information asymmetries and agency costs vary. While we demonstrate that the connected-VC-effect gets more important for companies that suffer from greater geographical and technological distances, further research should focus on institutional distance as well as on company-specific and industry-specific opacity. Another promising research area is to analyze the connected-VC-effect in other types of cooperations between companies. We rely on strategic alliances, but connected VCs may be beneficial in joint ventures and other business relationships such as licensing, distribution, or franchising, too. Finally, we only touched on the relationship between the connected-VCparticipation and success. More research is required to improve our understanding of the mechanisms that drive this relationship.

Finally, it could be interesting to analyze whether we observe effects in the other direction as well. While this paper focused on the question whether prior connections between VCs help in establishing strategic alliances between companies from connected-VCs' portfolios, future research could study whether connections through strategic alliances lead to connections in future VC syndicates.

\section{References}

Ai, C., Norton, E.C., 2003. Interaction terms in logit and probit models. Econ. Lett. 80, 123-129.

Aoki, M., 2000. Information and governance in the Silicon Valley model. In: Vives, X. (Ed.), Corporate Governance: Theoretical and Empirical Perspectives. Cambridge University Press, Cambridge, UK. 
Barry, C.B., Muscarella, C.J., Peavy Iii, J.W., Vetsuypens, M.R., 1990. The role of venture capital in the creation of public companies: evidence from the going-public process. J. Financ. Econ. 27, 447-471.

Baum, J.A., Calabrese, T., Silverman, B.S., 2000. Don't go it alone: alliance network composition and startups' performance in Canadian biotechnology. Strateg. Manag. J. 21, 267-294.

Bena, J., Li, K., 2014. Corporate innovations and mergers and acquisitions. J. Financ. 69, 1923-1960.

Bertoni, F., Tykvová, T., 2015. Does governmental venture capital spur invention and innovation? Evidence from young European biotech companies. Res. Policy 44, 925-935.

Brander, J.A., Amit, R., Antweiler, W., 2002. Venture-capital syndication: improved venture selection vs. the value-added hypothesis. J. Econom. Manag. Strategy 11, 423-452.

Brinster, L., Hopp, C., Tykvová, T., 2020. The role of strategic alliances in VC exits: evidence from the biotechnology industry. Ventur. Cap. 22 , 281-313.

Chan, S.H., Kensinger, J.W., Keown, A.J., Martin, J.D., 1997. Do strategic alliances create value? J. Financ. Econ. 46, 199-221.

Cumming, D., Fleming, G., Suchard, J.-A., 2005. Venture capitalist value-added activities, fundraising and drawdowns. J. Bank. Financ. 29, 295-331.

Das, T.K., Teng, B.-S., 1999. Managing risks in strategic alliances. Acad. Manag. Perspect. 13, 50-62.

Das, T.K., Teng, B.-S., 2000. Instabilities of strategic alliances: an internal tensions perspective. Organ. Sci. 11, 77-101.

Das, T.K., Teng, B.-S., 2001. Trust, control, and risk in strategic alliances: an integrated framework. Organ. Stud. 22, 251-283.

Deeds, D.L., Decarolis, D., Coombs, J.E., 1997. The impact of firmspecific capabilities on the amount of capital raised in an initial public offering: evidence from the biotechnology industry. J. Bus. Ventur. 12, 31-46.

Diestre, L., Rajagopalan, N., 2012. Are all 'sharks' dangerous? New biotechnology ventures and partner selection in R\&D alliances. Strateg. Manag. J. 33, $1115-1134$.

Dyer, J.H., Chu, W., 2003. The role of trustworthiness in reducing transaction costs and improving performance: empirical evidence from the United States, Japan, and Korea. Organ. Sci. 14, 57-68.

Fonti, F., Maoret, M., Whitbred, R., 2017. Free-riding in multi-party alliances: the role of perceived alliance effectiveness and peers' collaboration in a research consortium. Strateg. Manag. J. 38, 363-383.

Gompers, P.A., 1995. Optimal investment, monitoring, and the staging of venture capital. J. Financ. 50, $1461-1489$.

Grilli, L., Murtinu, S., 2014. Government, venture capital and the growth of European high-tech entrepreneurial firms. Res. Policy 43, 1523-1543.

Gulati, R., 1995. Social structure and alliance formation patterns: a longitudinal analysis. Adm. Sci. Q. 619-652.

Gulati, R., 1998. Alliances and networks. Strateg. Manag. J. 19, 293-317.

Gulati, R., 1999. Network location and learning: the influence of network resources and firm capabilities on alliance formation. Strateg. Manag. J. 20, 397-420.

Gulati, R., Singh, H., 1998. The architecture of cooperation: managing coordination costs and appropriation concerns in strategic alliances. Adm. Sci. Q. 781-814.

Hamel, G., Doz, Y.L., Prahalad, C.K., 1989. Collaborate with your competitors and win. Harv. Bus. Rev. 67, 133-139.

Hellmann, T., Puri, M., 2000. The interaction between product market and financing strategy: the role of venture capital. Rev. Financ. Stud. 13, 959-984.

Hellmann, T., Puri, M., 2002. Venture capital and the professionalization of start-up firms: empirical evidence. J. Financ. 57, $169-197$.

Hochberg, Y.V., 2012. Venture capital and corporate governance in the newly public firm. Rev. Finance 16, 429-480.

Hochberg, Y.V., Ljungqvist, A., Lu, Y., 2007. Whom you know matters: venture capital networks and investment performance. J. Financ. 62, 251-301.

Hochberg, Y.V., Ljungqvist, A., Lu, Y., 2010. Networking as a barrier to entry and the competitive supply of venture capital. J. Financ. 65, 829-859.

Hsu, D.H., 2004. What do entrepreneurs pay for venture capital affiliation? J. Financ. 59, 1805-1844.

Kaplan, S.N., Strömberg, P., 2001. Venture capitals as principals: contracting, screening, and monitoring. Am. Econ. Rev. 91, 426-430.

Kaplan, S.N., Strömberg, P., 2004. Characteristics, contracts, and actions: evidence from venture capitalist analyses. J. Financ. 59, $2177-2210$.

Kortum, S., Lerner, J., 2000. Assessing the contribution of venture capital to innovation. RAND J. Econ. 31, 674-692.

Lerner, J., 1994. Venture capitalists and the decision to go public. J. Financ. Econ. 35, 293-316.

Lerner, J., 1995. Venture capitalists and the oversight of private firms. J. Financ. 50, 301-318.

Lerner, J., Shane, H., Tsai, A., 2003. Do equity financing cycles matter? Evidence from biotechnology alliances. J. Financ. Econ. 67, $411-446$.

Lindsey, L., 2008. Blurring firm boundaries: the role of venture capital in strategic alliances. J. Financ. 63, 1137-1168.

Megginson, W.L., Weiss, K.A., 1991. Venture capitalist certification in initial public offerings. J. Financ. 46, 879-903.

Mitchell, W., Singh, K., 1996. Survival of businesses using collaborative relationships to commercialize complex goods. Strateg. Manag. J. 17, 169-195.

Owen, S., Yawson, A., 2013. Information asymmetry and international strategic alliances. J. Bank. Financ. 37, 3890-3903.

Ozmel, U., Reuer, J.J., Gulati, R., 2013a. Signals across multiple networks: how venture capital and alliance networks affect interorganizational collaboration. Acad. Manag. J. 56, 852-866.

Ozmel, U., Robinson, D.T., Stuart, T.E., 2013b. Strategic alliances, venture capital, and exit decisions in early stage high-tech firms. J. Financ. Econ. 107, 655-670. Pisano, G.P., 1994. Knowledge, integration, and the locus of learning: an empirical analysis of process development. Strateg. Manag. J. 15, 85-100.

Popov, A., Roosenboom, P., 2012. Venture capital and patented innovation: evidence from Europe. Econ. Policy 27, 447-482.

Reuer, J.J., Zollo, M., Singh, H., 2002. Post-formation dynamics in strategic alliances. Strateg. Manag. J. 23, 135-151.

Robinson, D.T., Stuart, T.E., 2007a. Financial contracting in biotech strategic alliances. J. Law Econ. 50, 559-596.

Robinson, D.T., Stuart, T.E., 2007b. Network effects in the governance of strategic alliances. J. Law Econ. Org. 23, $242-273$.

Rothaermel, F.T., 2001a. Complementary assets, strategic alliances, and the incumbent's advantage: an empirical study of industry and firm effects in the

biopharmaceutical industry. Res. Policy 30, 1235-1251.

Rothaermel, F.T., 2001b. Incumbent's advantage through exploiting complementary assets via interfirm cooperation. Strateg. Manag. J. 22, 687-699.

Rothaermel, F.T., Deeds, D.L., 2004. Exploration and exploitation alliances in biotechnology: a system of new product development. Strateg. Manag. J. 25, 201-221.

Sadowski, B., Duysters, G., 2008. Strategic technology alliance termination: an empirical investigation. J. Eng. Technol. Manag. 25, 305-320.

Sahlman, W.A., 1990. The structure and governance of venture-capital organizations. J. Financ. Econ. 27, $473-521$.

Shan, W., Walker, G., Kogut, B., 1994. Interfirm cooperation and startup innovation in the biotechnology industry. Strateg. Manag. J. 15, 387-394.

Singh, J., 2008. Distributed R\&D, cross-regional knowledge integration and quality of innovative output. Res. Policy 37, 77-96.

Singh, K., Mitchell, W., 2005. Growth dynamics: the bidirectional relationship between interfirm collaboration and business sales in entrant and incumbent alliances. Strateg. Manag. J. 26, 497-521.

Sørensen, M., 2007. How smart is smart money? A two-sided matching model of venture capital. J. Financ. 62, 2725-2762.

Stuart, T.E., 2000. Interorganizational alliances and the performance of firms: a study of growth and innovation rates in a high-technology industry. Strateg. Manag. J. $21,791-811$.

Tian, X., 2012. The role of venture capital syndication in value creation for entrepreneurial firms. Rev. Finance 16, $245-283$.

Tykvová, T., 2018. Venture capital and private equity financing: an overview of recent literature and an agenda for future research. J. Bus. Econ. 88, 325-362.

Wang, H., Wuebker, R.J., Han, S., Ensley, M.D., 2012. Strategic alliances by venture capital backed firms: an empirical examination. Small Bus. Econ. 38, $179-196$.

White, S., Siu-Yun Lui, S., 2005. Distinguishing costs of cooperation and control in alliances. Strateg. Manag. J. 26, 913-932.

Williams, R., 2009. Using heterogeneous choice models to compare logit and probit coefficients across groups. Sociol. Methods Res. 37, 531-559.

Yang, H., Zheng, Y., Zhao, X., 2014. Exploration or exploitation? Small firms' alliance strategies with large firms. Strateg. Manag. J. 35, 146-157. 